\title{
IMPROVING SOIL STABILITY BY USING POLYETHYLENE GEOGRID
}

\author{
B.M.Patil ${ }^{1}$, S.B.Bhutekar ${ }^{2}$ \\ ${ }^{1}$ Faculty, Civil Engineering Department, Jawaharlal Nehru Engineering College, Aurangabad, Maharashtra, India. \\ ${ }^{2}$ Lecturer, Civil Engineering Department, MGM's Polytechnic, Aurangabad, Maharashtra, India.
}

\begin{abstract}
Soil performance plays vital role in road construction as the sub grade of road is the most important element for the designed life of road. In this paper we have made an attempt to enhance soil stability by using polyethylene geogrid which made from the waste material. The present study investigates the improvement in the CBR value of lateritic soil by using geogrids at different depths. We have conducted CBR test (unsoaked) on lateritic soil specimen. The result shows the significant improvement in CBR value as it predicts better performance of road pavement with economical approach.
\end{abstract}

Keywords: CBR, Polyethylene geogrid, lateritic soil, Stabilization of soil. - $* * *$

\section{INTRODUCTION}

Since the beginning of mankind, the human races have attempted to create new ideas for the construction of structural system. There are various techniques to improve the CBR value of the soil for road construction by using polyethylene geogrid at different depths of sub grade course of flexible pavements, which helps to improve CBR value. The load coming on the road crust is transferred to the underlying soil. If the soil supporting the road crust is weaker, the crust thickness of road increases, which leads to increase the cost of construction and most likely road pavement failures in the nearest future. Construction by geogrid helps to reduce cost of materials to be hauled from far distance, rather the initial earth materials found on the construction site is used for the road pavement. Reinforcement geosynthetics and geogrids are used for different applications in geotechnical engineering such as reinforced earth fills, retaining walls, embankments, road pavement and foundations. Geosynthetics possesses high tensile strength, better elongation and high stiffness.

\subsection{Objectives}

$>$ To improve the structural integrity of soils in roadways, walls etc.

$>$ To reduce pavement thickness and subsequently the cost of project.

$>$ To improve bearing capacity of soil.

$>$ To improve strength and stiffness of pavement which ultimately reduces pot holes in the road.

$>$ Utilization of land which is not adequate for road pavement.

\subsection{Mechanism}

Geogrids are synthetic material made from polymers such as polypropylene, polyethylene or polyester and are used widely in Civil Engineering applications to provide tensile reinforcement of soil. Fig 1 shows they are in the form of open grids so that soil can strike through the apertures and the two materials interlock together to give composite behavior. They are used in the construction of retaining walls, steep slopes, roadway bases and foundations. The high demand and application of Geogrids in construction are due to the fact that it is good in tension and has a higher ability to distribute load across a large area which ultimately increases life of road.

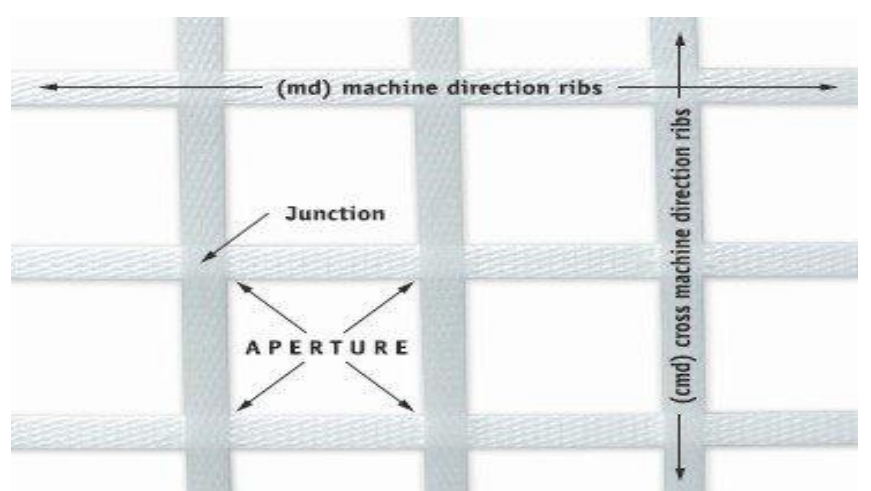

Fig -1: Polyethylene geogrid sample

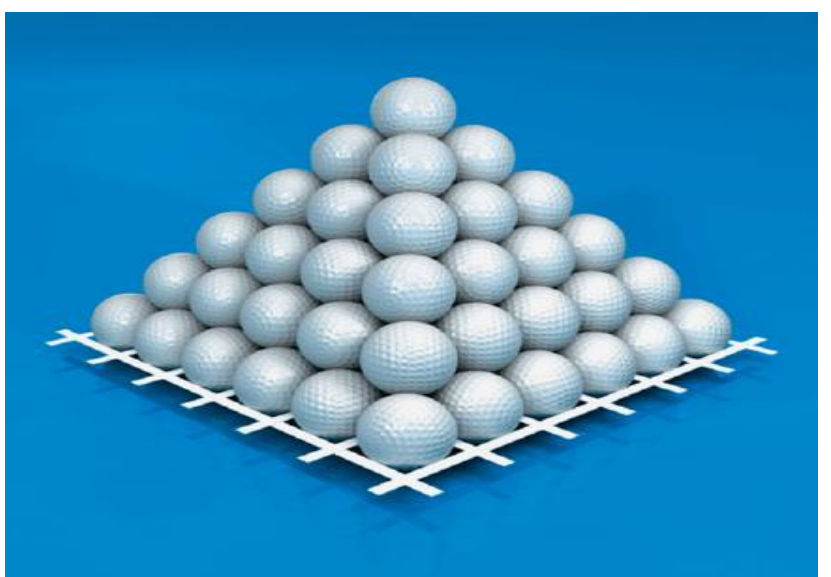

Fig -2: Representation of soil sustained due to geogrid 


\section{EXPERIMENTAL INVESTIGATION}

In this project the soil was collected from N-6, Cidco Aurangabad (M.S.). The soil used is lateritic soil and various tests had conducted on it in the laboratory on the two different specimen. The material which has been used for soil stabilization is polyethylene grid which is made from waste plastic material. The test results are given in Table 1.

Table 1: Properties of soil

\begin{tabular}{|l|l|}
\hline Basic Engineering Properties & \\
\hline Specific Gravity & 2.23 \\
\hline Optimum moisture content (\%) & 15.01 \\
\hline MDD without geogrid $(\mathrm{gm} / \mathrm{cc})$ & $5.46 \times 10^{-4}$ \\
\hline
\end{tabular}

\subsection{Methodolgy}

CBR is one of the most significant test to determine the strength of sub grade soil, sub base and base course material for design of thickness of pavement. For this study we have taken two same specimen of lateritic soil (unsoaked) named as $S_{1}$ and $S_{2}$. The CBR test conducted for $S_{1}$ specimen without geogrid and $S_{2}$ with polyethylene geogrid respectively. In $S_{2}$ specimen we placed two layers of polyethylene mesh one at $20 \mathrm{~mm}$ above from the bottom and another at middle of mould as shown in fig no. 4 .

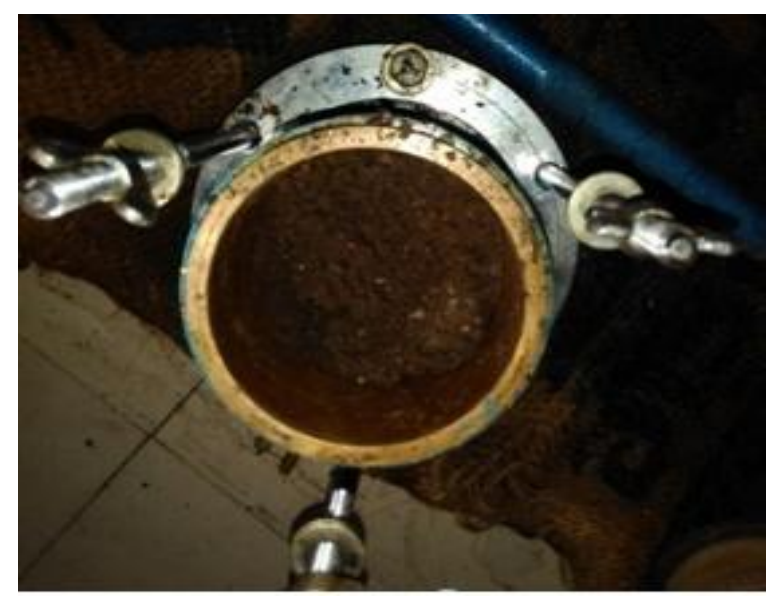

Fig -3: $\mathrm{S}_{1}$ Soil sample without geogrid

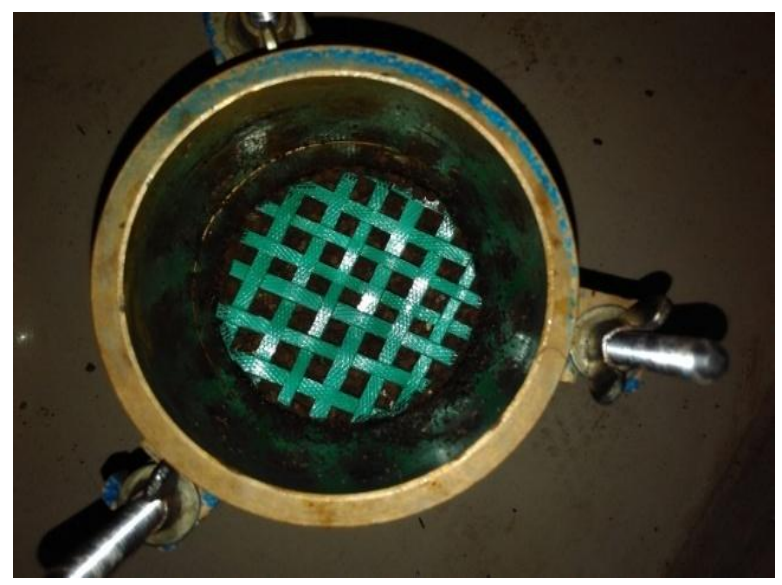

Fig -4: $\mathrm{S}_{2}$ Soil sample with polyethylene geogrid

\subsection{Result and Discussion}

Penetration behavior of lateritic soil against compression was examined. Load penetration curve has been plotted for specimen without geogrid and with polyethylene geogrid. Table no. 2 shows the load was applied on the specimen in $\mathrm{Kg}$ for corresponding value of penetration for CBR test. Chart no. 1 compares the typical plots of load-penetration curves for two different specimens $S_{1}$ and $S_{2}$. From this it is cleared that for soil specimen with polyethylene grid requires more load for penetration than that of the specimen without geogrid.

Table -2: Observation table for load in $(\mathrm{Kg})$ for specimen without and with geogrid

\begin{tabular}{|l|l|l|}
\hline $\begin{array}{l}\text { Penetration } \\
\text { Plunger (mm) }\end{array}$ & $\begin{array}{l}\text { Load on piston } \\
\text { in Kg (Without } \\
\text { Geogrid) }\end{array}$ & $\begin{array}{l}\text { Load on piston } \\
\text { ing Keogrid) } \\
\text { Geon }\end{array}$ \\
\hline 2.5 & 67.27 & 95.81 \\
\hline 5 & 93.78 & 138.63 \\
\hline 7.5 & 106.01 & 150.86 \\
\hline 10 & 116.2 & 161.05 \\
\hline 12.5 & 126.39 & 169.21 \\
\hline
\end{tabular}

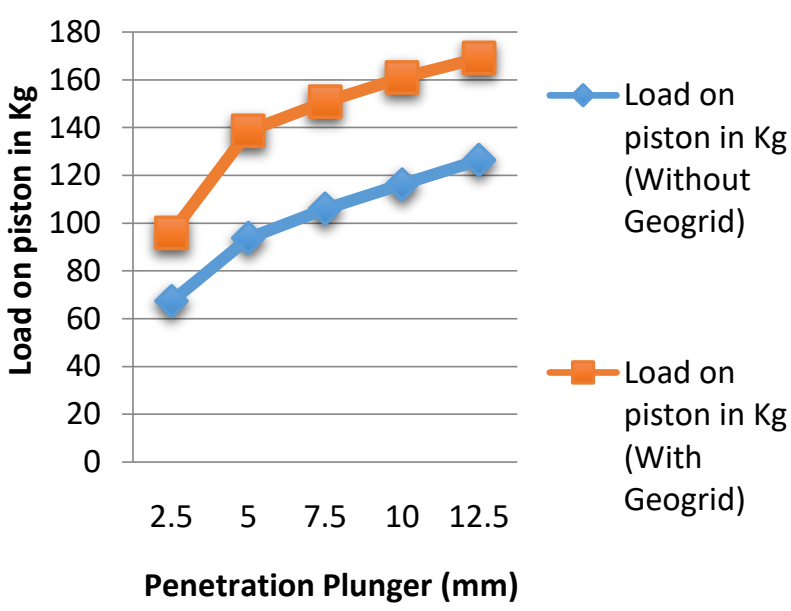

Chart-1: Load on piston in $(\mathrm{Kg})$ Vs Penetration $(\mathrm{mm})$

The CBR values have been calculated for the load corresponding to the penetration of $2.5 \mathrm{~mm}$ and $5 \mathrm{~mm}$ up to $12.5 \mathrm{~mm}$. CBR is measure of resistance of material to standard plunger in flexible road pavements. Normally the CBR value at $2.5 \mathrm{~mm}$ penetration which is higher than at $5 \mathrm{~mm}$ is reported as CBR value of the material (IS-2720-161979).So CBR value for soil specimen with polyethylene geogrid is $6.99 \%$ which is greater than that of soil specimen without geogrid. Comparison of CBR test results are tabulated in table no. 3 .

Table -3: CBR value without and with geogrid 


\begin{tabular}{|l|l|l|}
\hline $\begin{array}{l}\text { Penetration } \\
\text { Plunger (mm) }\end{array}$ & $\begin{array}{l}\text { CBR Value } \\
\text { in \% } \\
\text { (Without } \\
\text { geogrid) }\end{array}$ & $\begin{array}{l}\text { CBR Value } \\
\text { in \% } \\
\text { (With geogrid) }\end{array}$ \\
\hline 2.5 & 4.91 & 6.99 \\
\hline 5 & 4.56 & 6.74 \\
\hline 7.5 & 4.03 & 5.73 \\
\hline 10 & 3.65 & 5.06 \\
\hline 12.5 & 3.51 & 4.7 \\
\hline
\end{tabular}

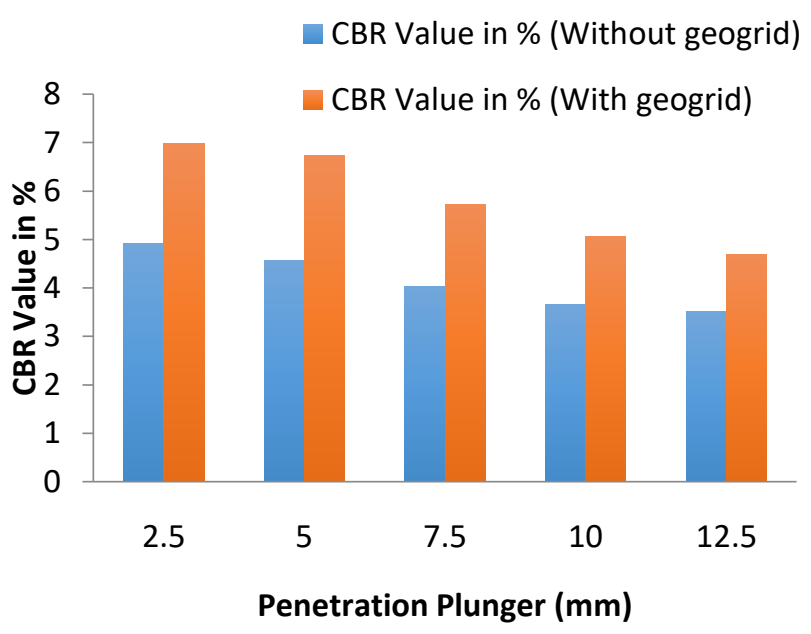

Chart-2: Graph showing CBR values of two specimens for corresponding penetration in $\mathrm{mm}$

\section{CONCLUSION}

From this study, it is observed that CBR values for the soil specimen with polyethylene geogrid are higher than soil specimen without geogrid. On comparing two different specimens it is evaluated that soil used with polyethylene geogrid shows considerable increase in CBR value than that of soil used with no geogrid. In this study used geogrid is a waste plastic material which may pollute the soil if it is not disposed of properly. By using this waste material for soil stabilization, soil pollution can be reduced. It has been experimented that soil specimen $\left(S_{2}\right)$ with polyethylene geogrid has more potential against applied load as compare to soil sample without geogrid. These CBR results are correlated with thickness of flexible pavements. Thus, study has been concluded that CBR value of lateritic soil can be increased by using polyethylene geogrid as a soil stabilizer.

\section{REFERENCES}

[1] P. K. Kolay, S. Kumar, and D. Tiwari "Improvement of Bearing Capacity of Shallow Foundation on geogrid Reinforced Silty Clay and Sand" Journal of the Transportation Research Board, No. 2462, Transportation Research Board of the National Academies, Washington, 2014, pp. 98-108.

[2] Mr.Akolade"Reinforcement of Subgrade Soils with the Use of Geogrids" International Journal of Science and Research (IJSR) Paper ID: 02014772 Volume 3 Issue 6, June 2014
[3] I.L.Muthreja1, Dr. R. R. Yerpude, Dr. J. L. Jethwa "Application of Geo-Grid Reinforcement Techniques for Improving Waste Dump Stability in Surface Coal Mines: Numerical Modeling and Physical Modeling"

[4] Debakanta Mishra, Yu Qian, Hasan Kazmee, and Erol Tutumluer "Investigation of Geogrid-Reinforced Railroad Ballast Behaviour Using Large-Scale Triaxial Testing Element Modeling" Transportation Research Record: Journal of the Transportation Research Board, No. 2462,Transportation Research Board of the National Academies, Washington.

[5] V. Mallikarjuna, and T. Bindu Mani "Soil Stabilization Using Plastic Waste", International Journal of Research in Engineering and Technology, Vol. 05, May 2016.

[6] Kalumba D and Chebet F.C."Utilization of polyethylene (plastic) shopping bags waste for soil improvement in sandy soil”. 